\title{
Association of Heparan Sulfate Proteoglycan with the Neurofibrillary Tangles of Alzheimer's Disease
}

\author{
George Perry, ${ }^{1}$ Sandra L. Siedlak, ${ }^{1}$ Peggy Richey, ${ }^{1}$ Mitsuru Kawai,' Patrick Cras,' Rajesh N. Kalaria, ${ }^{1}$ Pamela \\ G. Galloway, ${ }^{1}$ Jan Miriam Scardina, ${ }^{2}$ Barbara Cordell, ${ }^{2}$ Barry D. Greenberg, ${ }^{3}$ Steven R. Ledbetter, ${ }^{3}$ and \\ Pierluigi Gambetti ${ }^{1}$ \\ ${ }^{1}$ Division of Neuropathology, Institute of Pathology, Case Western Reserve University, Cleveland, Ohio 44106, ${ }^{2}$ California \\ Biotechnology, Mountain View, California 94043, and ${ }^{3}$ Upjohn Company, Kalamazoo, Michigan 49001
}

\begin{abstract}
The major intracytoplasmic lesion of Alzheimer's disease is the neurofibrillary tangle (NFT), which is primarily composed of paired helical filaments (PHFs). The mechanism responsible for the formation of PHFs, as well as their insolubility and apparent heterogeneity, is unknown. We found that basic fibroblast growth factor (bFGF) binds to heparinase-sensitive sites in NFTs. bFGF binding is due to a heparan sulfate proteoglycan (HSPG) immunocytochemically identified in NFTs. In the presence of polycations (e.g., $\mathrm{Ca}^{2+}$ ), HSPG will bind to free carboxyl groups in NFT proteins. HSPG binding may play a role in transforming normal soluble proteins into insoluble PHFs.
\end{abstract}

The composition and mode of formation of the neurofibrillary tangle (NFT), a distinctive neuronal lesion, composed of paired helical filaments (PHFs) in Alzheimer's disease (AD), is controversial (Perry, 1987). Two features that make the understanding of the NFT difficult are the complexity of their composition and their insolubility. Although it has recently been demonstrated that a soluble form of PHF is solely composed of the microtubule-associated protein tau (Greenberg and Davies, 1990; Lee et al., 1991), NFTs are largely insoluble and contain other antigens distinct from tau, including neurofilaments (Gambetti et al., 1987; Mulvihill and Perry, 1989) and tropomyosin (Galloway et al., 1990). The mechanism responsible for the incorporation of these presumably associated proteins into NFTs is unknown.

In a previous study of the role of growth factors in the formation of senile plaques, we found that basic fibroblast growth factor (bFGF) binds to NFTs (Perry et al., 1990a,b; Siedlak et al., 1991). We now show that bFGF is bound to a heparan sulfate proteoglycan (HSPG) that is also present in NFTs. We found that HSPG binds to the free carboxyl groups of the PHFs and suggest that similar interactions may mediate the binding of other proteins to NFTs and render them insoluble.

\footnotetext{
Received Apr. 23, 1991; accepted June 10, 1991.

We thank Sandy Bowen for manuscript preparation and Drs. L. Culp and T. Rosenberry for advice. This work was supported by NIH Grants AG007552, AG009287, and AG00795. G.P. is the recipient of NIH Research Career Development Award K04-AG00415, and P.C. and M.K. are fellows of the Fogarty International Center.

Correspondence should be addressed to George Perry, Ph.D., Division of Neuropathology, Case Western Reserve University, 2085 Adelbert Road, Cleveland, OH 44106.

Copyright (C) 1991 Society for Neuroscience $0270-6474 / 91 / 113679-05 \$ 05.00 / 0$
}

\section{Materials and Methods}

Tissue. The hippocampal gyrus was taken from nine pathologically confirmed (Khachaturian, 1985) cases of AD (mean age, $82 \mathrm{yr}$; range, 73$88 \mathrm{yr}$ ) and two controls (60 and $64 \mathrm{yr}$ ) and placed in methacarn (methanol 6 : chloroform 3 : acetic acid 1), a fixative that makes no covalent modification, for $24-48 \mathrm{hr}$ before dehydration and embedding in paraffin. Tissue from two AD cases (69 and $73 \mathrm{yr}$ ) was frozen in liquid nitrogen-chilled isopentane. We also used a Bouin's-Hollande fixed, paraffin-embedded sample taken from the frontal cortex of an AD case (74 yr) taken at biopsy (gift of Dr. S. Chou, Cleveland Clinic Foundation). Paraffin-embedded sections were cut at $6 \mu \mathrm{m}$, and frozen sections, at $10 \mu \mathrm{m}$.

Antibodies. The following antibodies were used: (1) monoclonal antibody (Ig fraction) to an epitope located in the carboxyl terminal of bFGF, 48.1 (J. M. Scardina, unpublished observations), and (2) rabbit antiserum to an HSPG core protein (Ledbetter et al., 1987; Noonan et al., 1988).

Protein preparations. The following proteins were used: (1) human bFGF (154 amino acid form) recombinantly produced in Escherichia coli and purified to homogeneity by using anion exchange chromatography, (2) heparan sulfate proteoglycan core protein isolated from Engelbreth-Holm-Swarm tumor (Ledbetter et al., 1985, 1987; Noonan et al., 1988), and (3) ovalbumin obtained from Sigma.

Preparalion of peroxidase-protein conjugates. Peroxidase-conjugated proteins were prepared by coupling horseradish peroxidase (HRP) to ovalbumin (as a control), bFGF, or HSPG core protein. Briefly, proteins were dialyzed into $0.9 \% \mathrm{NaCl}$ in $1 \mathrm{M} \mathrm{NaHCO}_{3}, \mathrm{pH} 9.5$, and incubated for $16 \mathrm{hr}$ at room temperature (RT) with activated peroxidase Pierce at a ratio adjusted for the molecular weight of the protein to be coupled. Excess reactive groups were blocked with $0.2 \mathrm{M}$ Tris, and $1 \%$ bovine serum albumin, followed by dialysis in $150 \mathrm{~mm} \mathrm{NaCl}$ and $50 \mathrm{~mm}$ Tris, pH 6.8 .

Staining. Sections were immunostained with the antibodies by employing the peroxidase-antiperoxidase procedure (Sternberger, 1986) with 3,3'-diaminobenzidine as cosubstrate. Prior to immunostaining, sections were treated with $3 \% \mathrm{H}_{2} \mathrm{O}_{2}$ in methanol for 30 min to block endogenous peroxidase. HRP-protein conjugates were visualized by development for peroxidase activity as above. In some experiments, tissue sections were treated with $0.2 \mathrm{M} \mathrm{NaOH}$ at RT for $1 \mathrm{hr}$ prior to staining. In control experiments, primary antibodies were omitted and the results compared with our experimentals. The extent of ligand binding was evaluated by comparing staining intensities.

Competition, adsorption, and binding experiments. In order to ascertain the specificity of bFGF binding to NFT in sections, we incubated bFGF at $4^{\circ} \mathrm{C}$ for $22 \mathrm{hr}$ with either $100 \mu \mathrm{g} / \mathrm{ml}$ heparin, $5 \mathrm{mg} / \mathrm{ml}$ polylysine, or $30 \mu \mathrm{g} / \mathrm{ml}$ protamine and then applied the solutions to the sections followed by immunostaining with monoclonal antibody to bFGF 48.1. In other experiments, we applied $0.5 \mu \mathrm{g} / \mathrm{ml}$ bFGF-HRP together with various concentrations of bFGF $(0.15 \mathrm{ng}$ to $160 \mu \mathrm{g} / \mathrm{ml}$ serially diluted $1: 4)$ to the section and incubated for $16 \mathrm{hr}$ at $4^{\circ} \mathrm{C}$. In adsorption experiments, the antibody was incubated with antigen for $16 \mathrm{hr}$ at $4^{\circ} \mathrm{C}$ before application to tissue sections. Binding of bFGF or HSPG to NFT without HRP labeling was assessed by incubating the tissue section with ligand, rinsing with the same buffer used for incubation, fixing with $3.7 \%$ formaldehyde for $5 \mathrm{~min}$, and then immunostaining with an antibody to the ligand, but at a greater dilution that does not identify endogenous 


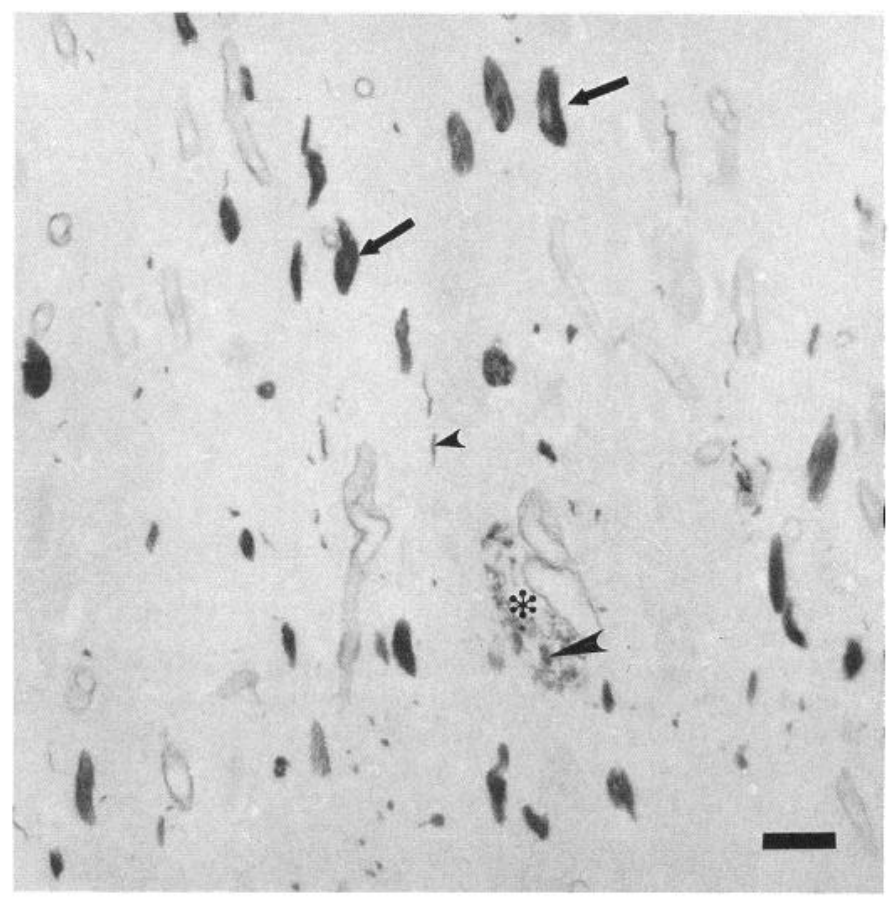

Figure 1. bFGF binds to neurofibrillary tangles (arrows), senile plaque neurites (large arrowheads), and neuropil threads (small arrowheads) as well as to amyloid deposits (*). In control sections (not shown), bFGF binding was limited to blood vessels and the few age-related NFTs. Scale bar, $25 \mu \mathrm{m}$.

HSPG. In control experiments, the sections were stained with the same antibody dilution minus the ligand preincubation.

$p H$ and $\mathrm{Ca}^{2+}$ dependence of $b F G F$ and $H S P G$ binding. The influence of $\mathrm{pH}$ on bFGF or HSPG binding to tissue sections was evaluated by incubating ligand or ligand-HRP at $\mathrm{pH} 3.1,4.1,5.0,6.0,7.0,7.6,8.0$, $9.0,9.9$, and 10.8 by using $0.1 \mathrm{M}$ Bis-Tris- $\mathrm{HCl}$ from $\mathrm{pH} 3.1$ to $6.0,0.1$ $\mathrm{M}$ Tris- $\mathrm{HCl}$ for $\mathrm{pH} 7.0-9.0$, and $0.05 \mathrm{M}$ cyclohexylaminopropane sulfonic acid-HCl for pH 9.9 and 10.8 as buffers. The dependence on $\mathrm{Ca}^{2+}$ was determined by using $\mathrm{Ca}^{2+} /$ EGTA buffers and ratios of $0.3,0.5$, $0.75,0.9,1.0,1.05,1.25,1.5$, and 3.0 with 2 mM EGTA (Potter and Gergely, 1975) in $150 \mathrm{~mm} \mathrm{NaCl}$ and $50 \mathrm{~mm}$ Tris- $\mathrm{HCl}, \mathrm{pH} 7.85$. Greater than $1 \mathrm{~mm}$ free $\mathrm{Ca}^{2+}$ solutions omitted EGTA.

Protein and sugar modification treatments. Paraffin-embedded tissue sections were incubated with one of the following: (1) $0.05 \mathrm{U} / \mathrm{ml}$ of either heparinase $(0.05 \mathrm{U} / \mathrm{ml}, \mathrm{ICN}$, or $1 \mathrm{U} / \mathrm{ml}$, Sigma), heparinase $2(1$ $\mathrm{U} / \mathrm{ml}$, Sigma), heparitinase ( $0.05 \mathrm{U} / \mathrm{ml}, \mathrm{ICN}$ or Seikagaku), or a combination of heparinase and heparitinase at RT for $22 \mathrm{hr}$ in $20 \mathrm{~mm} \mathrm{CaCl}_{2}$ and $10 \mathrm{~mm}$ Tris, pH 7.0 (Schubert et al., 1988). The specificity of heparinase or heparitinase treatment for heparan removal from sections was shown by comparison with the effect of $0.01 \mu \mathrm{g} / \mathrm{ml}$ chondroitinase $\mathrm{ABC}(\mathrm{ICN})$ in $20 \mathrm{~mm} \mathrm{CaCl}$ and $10 \mathrm{~mm}$ Tris, $\mathrm{pH} 8.0$, incubated at RT for $22 \mathrm{hr}$ or $400 \mu \mathrm{g} / \mathrm{ml}$ trypsin (Worthington) at $37^{\circ} \mathrm{C}$ for $10 \mathrm{~min}$ in 300 $\mathrm{mm} \mathrm{NaCl}, 20 \mathrm{mM} \mathrm{CaCl}_{2}$, and $50 \mathrm{~mm}$ Tris, $\mathrm{pH} \mathrm{7.6.} \mathrm{As} \mathrm{controls} \mathrm{for} \mathrm{any}$ residual protease activity in the heparinase preparation, the inhibitor $0.5 \mathrm{~mm}$ leupeptin, $1 \mathrm{~mm}$ phenylmethylsulfonyl fluoride, or exogenous protein (1 mg actin $/ \mathrm{ml}$ ) was used. (2) Two percent periodic acid for 16 $\mathrm{hr}$ at RT to modify sugar residues (Behrouz et al., 1989); (3) nitrous acid consisting of $0.24 \mathrm{M}$ sodium nitrite in $1.8 \mathrm{M}$ acetic acid for $90 \mathrm{~min}$ at RT to modify N-linked sulfates (Hirabayashi et al., 1989); (4) 4 $\mathrm{U} / \mathrm{ml}$ neuraminidase (Sigma, type VI) in $0.2 \mathrm{M}$ acetate, $\mathrm{pH} 5.4$, for 2 $\mathrm{hr}$ at $37^{\circ} \mathrm{C}$ to remove sialic acid residues (Szumanska et al., 1987); (5) $0.1 \mathrm{~m}$ ethanolamine with the addition of $20 \mathrm{~mm}$ 1-ethyl-3-(3-dimethylaminopropyl) carbodiimide (carbodiimide) after $10 \mathrm{~min}$ at $37^{\circ} \mathrm{C}$ to block and convert carboxyl groups to secondary amines (Taniuchi et al., 1986); (6) $10 \mathrm{~mm}$ paraformaldehyde with $60 \mathrm{~mm}$ sodium cyano-

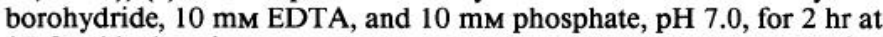
$37^{\circ} \mathrm{C}$ to block amino groups (Peterson et al., 1979); (7) $400 \mu \mathrm{g} / \mathrm{ml}$ alkaline phosphatase (Sigma, type VII-S, bovine intestinal) in $0.1 \mathrm{M}$ Tris, $\mathrm{pH}$ 8.0 , with $0.01 \mathrm{M}$ phenylmethylsulfonyl fluoride for $18 \mathrm{hr}$ followed by 2

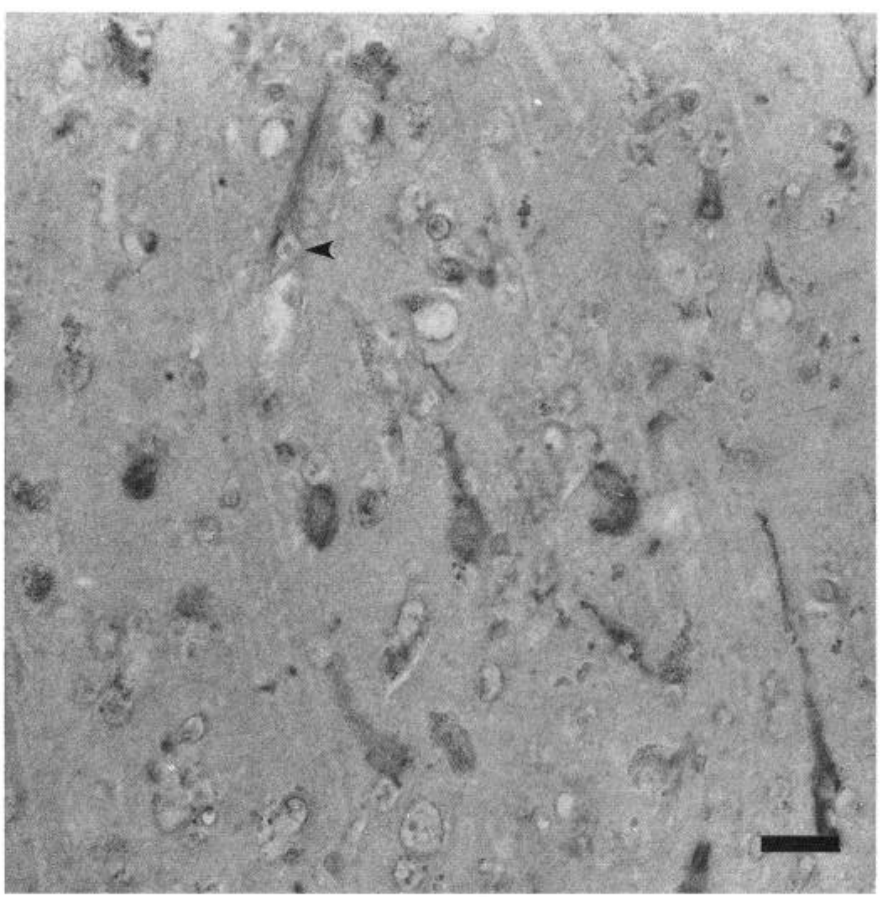

Figure 2. NFTs recognized by an antibody to HSPG; note that the NFTs recognized are intraneuronal. Nucleus is indicated by arrowhead. Additionally, intraneuronal granules are stained. No staining of NFTs or granules was seen in the absence of primary antibody. Scale bar, 25 $\mu \mathrm{m}$.

$\mathrm{U} / \mathrm{ml}$ acid phosphatase (Sigma; prostatic, $3200 \mathrm{U} / \mathrm{mg}$ ) in $0.1 \mathrm{~m}$ acetate, $\mathrm{pH} 5.0$, for $3 \mathrm{hr}$ at $37^{\circ} \mathrm{C}$ (Ueda et al., 1990); or (8) an unembedded methacarn-fixed tissue block of $3 \mathrm{~mm}$ thickness treated with $50 \%$ hydrofluoric acid for $48 \mathrm{hr}$ at $4^{\circ} \mathrm{C}$ (Mayor et al., 1990) to remove phosphate groups followed by paraffin embedding.

\section{Results}

bFGF bound to NFTs (Fig. 1) as well as to amyloid deposits of senile plaques, an extracellular filamentous lesion, and vessel walls in both control and AD cases. However, the binding was more prominent in the AD cases because of the larger number of NFTs and senile plaques. bFGF binding, regardless as to whether it was with NFTs, amyloid deposits, or vessels, had the characteristics shown in Table 1. bFGF showed saturable binding that appeared to be charge dependent since $\mathrm{Ca}^{2+}$ or other polycations as well as anions inhibited the binding. Since bFGF is known to bind to its receptor as well as to HSPG (Rifkin and Moscatelli, 1989; Yayon et al., 1991), bFGF binding to NFTs suggested that HSPGs might be present. The blocking of bFGF binding by treatment of tissue with heparinases or heparitinase

\begin{tabular}{|c|c|c|}
\hline & bFGF binding & $\begin{array}{l}\text { HSPG } \\
\text { binding }\end{array}$ \\
\hline pH & $7.0-10.0$ & $7.0-9.0$ \\
\hline $\mathrm{Ca}^{2+}$ & $<9.0 \times 10^{-6} \mathrm{M}$ & $1-25 \mathrm{~mm}$ \\
\hline Saturation & $0.5 \mu \mathrm{g} / \mathrm{ml}$ & - \\
\hline Inhibitors & $\begin{array}{l}\text { Heparin, polylysine, } \\
\text { protamine }\end{array}$ & - \\
\hline
\end{tabular}




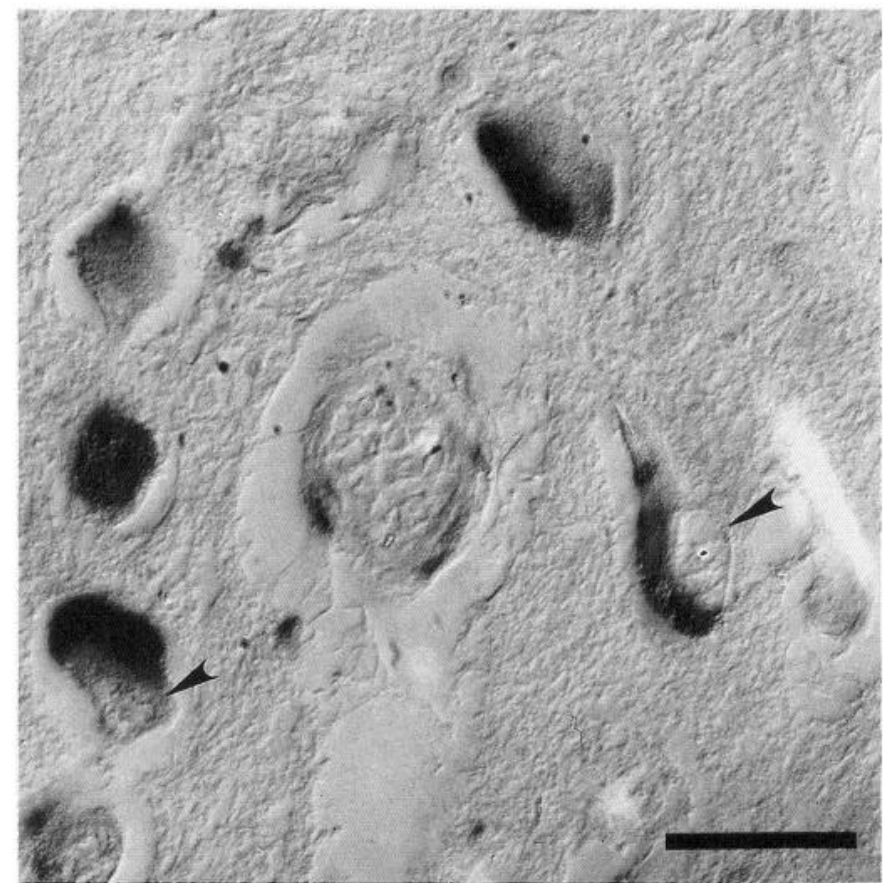

Figure 3. Intraneuronal NFTs, as well as extracellular NFTs (not shown), bind HSPG (HSPG-HRP). NFTs and intraneuronal granules recognized in neuronal cell bodies containing a nucleus are indicated by arrowheads. Differential interface contrast microscopy. Scale bar, $25 \mu \mathrm{m}$.

and the finding that an antiserum to an HSPG immunoreacted with NFTs (Fig. 2) supported bFGF interaction with HSPG in NFTs.

In order to understand how HSPGs are incorporated into NFTs, we characterized the HSPG-binding sites in NFTs by studying the properties of HSPG binding to NFTs (Fig. 3). The binding characteristics (Tables 1 and 2) suggest that $\mathrm{Ca}^{2+}$ acts as a bridge between anionic groups on HSPG, for example, removal of $\mathrm{N}$-linked sulfate groups by nitrous acid or sugar residue oxidation with periodate blocked HSPG binding to NFTs, and anions in NFTs. Consistent with the nonspecific nature of the polycation requirement, protamine (30-100 $\mu \mathrm{g} / \mathrm{ml})$ can sub- stitute for $\mathrm{Ca}^{2+}$. The $\mathrm{Ca}^{2+}$ inhibition of bFGF binding to HSPG (anion) in NFTs, is probably mediated by the cationic region of bFGF (Seno et al., 1990). HSPG binding to NFTs is probably to cationic groups in NFT; candidates include sugar residues of P-component, a serum glycoprotein (Kalaria and Grahovac, 1990; Kalaria et al., 1991), HSPG, phosphate, or carboxyl residues in PHF proteins. To distinguish among these possibilities, we treated sections with a variety of reagents that alter either sugar residues or amino acid side chains (Table 2). The same treatments were performed to characterize bFGF-binding sites. Alteration of sugar residues with reagents such as periodic acid or nitrous acid, neuraminidase, or heparinases generally increased HSPG binding to NFT. Thus, not only did HSPG not seem to be bound to sugar residues in NFTs, but the removal of sugar residues seemed to unmask new binding sites. In contrast, sugar-modifying treatments generally reduced bFGF binding. Moreover, treatment with formaldehyde-cyanoborohydride, to block amino groups, or with phosphatases or hydrofluoric acid (Mayor et al., 1990), to remove phosphate groups, did not decrease HSPG binding, indicating that free amino and phosphate groups in NFTs did not play a role in HSPG binding. Treatment with carbodiimide, which had no effect on bFGF binding, blocked HSPG binding, indicating that free carboxyl groups are required for HSPG binding to NFT.

A perplexing aspect of HSPG binding was that although HSPG is a protein of the extracellular matrix, HSPG was found in intraneuronal NFTs. Two alternative possibilities are that the association of HSPG with NFTs has occurred during postmortem autolysis or after extracellularization of NFTs. Both possibilities are unlikely because identical findings were obtained with the tissue obtained at biopsy (not shown), and we found that neurons with abundant cytoplasm and the nucleus had HSPG immunoreactivity (Fig. 2) and HSPG-binding sites (Fig. 3). Therefore, HSPG must be associated with intracellular NFTs in vivo.

\section{Discussion}

It has been well established that extracellular amyloid deposits of $\mathrm{AD}$ associate with molecules present in the extracellular matrix (Snow et al., 1988; Snow and Wight, 1989). However, there

Table 2. Effect of modifying treatments on bFGF and HSPG binding to NFTs

\begin{tabular}{llll} 
Treatment & Modification & bFGF & HSPG \\
\hline $\begin{array}{l}\text { Heparinases } \\
\text { Heparinase } 2\end{array}$ & Heparan removal & $\downarrow$ & - \\
$\begin{array}{l}\text { Heparitinase } \\
\text { Heparitinase }+\end{array} \quad \begin{array}{l}\text { Heparan removal } \\
\text { heparinase }\end{array}$ & Heparan removal & $\downarrow$ & - \\
$\begin{array}{l}\text { Heparitinase + heparitinase } \\
\text { with protease inhibitor }\end{array}$ & Heparan removal & $\downarrow$ & - \\
$\begin{array}{l}\text { Chondrotinase ABC } \\
\text { Neuraminidase }\end{array}$ & Chondroitin removal & $\downarrow$ & - \\
Trypsin & Sialic acid removal & - & - \\
Periodic acid & Proteolysis & $\downarrow$ & - \\
Nitrous acid & Sugar oxidation & - & - \\
Carbodiimide & N-linked sulfate removal & $\downarrow$ & $\uparrow$ \\
Formaldehyde & Carboxyl blockage & $\downarrow$ & $\uparrow$ \\
Phosphatases & Amino blockage & - & $\downarrow$ \\
Hydrofluoric acid & Phosphate removal & - & - \\
\hline
\end{tabular}


is considerable evidence that a glycoprotein, possibly a proteoglycan, is also associated with NFTs (Mann et al., 1988; Rosenblatt et al., 1989; Snow et al., 1989, 1990). The present study confirms and extends these findings by characterizing the biochemical basis for HSPG interaction with NFT. We have found that HSPG- and bFGF-binding sites are present in NFTs. Both these components are likely to be bound to an anion in NFTs provided by HSPG for bFGF and by carboxyl residues for HSPG. HSPG incorporation into NFTs occurs intraneuronally and is therefore not an artifact resulting from contamination of extracellular NFTs.

The presence of HSPG in NFTs may provide an explanation for two puzzling features of these inclusions: number of the components and the insolubility. HSPG is present in all known amyloid filaments in systemic and cerebral amyloidoses, and HSPG deposition is concomitant with amyloid filament formation (Snow et al., 1987a). Although amyloid filaments form in vitro by self-assembly, in vivo $\mathrm{HSPG}$ is likely to be required as an initiator of amyloid formation because of the low concentration of free amyloidogenic subunits (Kisilevsky and Snow, 1988; Snow and Wight, 1989). HSPG presumably plays this role because of its high negative charge, which allows it to concentrate and protect ligands from proteolysis while making insoluble complexes, as it apparently does for bFGF (Schreiber et al., 1985; Gospodarowicz and Cheng, 1986; Saksela et al., 1988).

HSPG may play a similar role in the formation of the abnormal filaments of NFTs. It is known that HSPG can bind proteins other than bFGF; some of these proteins such as amyloid precursor protein (Schubert et al., 1988, 1989; Klier et al., 1990), the asymmetric form of AChE (Brandon et al., 1985; Mesulam and Moran, 1987), and P-component (Hamazaki, 1987; Duong et al., 1989; Kalaria and Grahovac, 1990; Kalaria et al., 1991) have been found in NFTs. Therefore, the compositional complexity of NFTs may be due to the binding of proteins with multiple binding sites triggered by the presence of HSPG, a phenomenon similar to that occurring in the extracellular matrix in which various proteins self-assemble through multiple heteroand homologous bonds (Yurchenco and Johannes, 1990). Moreover, the binding of HSPG to carboxyl groups may explain why the identified PHF constituents, tau, neurofilaments, and tropomyosin, are abundant in glutamate and aspartate residues (Cleveland et al., 1977; Geisler et al., 1983; Matsumura et al., 1985). Consistent with this interpretation, antibodies to tau block HSPG binding (S.L. Siedlak and G. Perry, unpublished observations). While HSPG has not been detected in enriched PHF fractions (Sparkman et al., 1990; Lee et al., 1991; P. Mulvihill and G. Perry, unpublished observations), its association with PHF may depend on polycationic bridges not maintained in the isolation procedure. Although PHF may be primarily a polymer of tau, PHF formation may require incorporation of multiple components that are rendered insoluble as they are incorporated. HSPG's interaction with PHF proteins may provide the key to the understanding of these mechanisms.

\section{References}

Behrouz N, Defossez A, Delacourte A, Hublau P, Mazzucca M (1989) Alzheimer disease: glycolytic pretreatment dramatically enhances immunolabelling of senile plaques and cerebrovascular amyloid substance. Lab Invest 61:576-583.

Brandon E, Maldonado M, Garrido J, Inestrosa NC (1985) Anchorage of collagen-tailed acetylcholinesterase to the extracellular matrix is mediated by heparan proteoglycans. J Cell Biol 101:985-992.
Cleveland DW, Hawo SY, Kirschner MW (1977) Physical chemical properties of purified tau factor and the role of tau in microtubule assembly. J Mol Biol 1 16:227-247.

Duong T, Pommier EC, Scheibel AD (1989) Immunodetection of human serum amyloid P-component in Alzheimer's disease. Acta Neuropathol (Berl) 78:429-437.

Galloway PG, Mulvihill P, Siedlak S, Mijares M, Kawai M, Padgett H, Kim R, Perry G (1990) Immunochemical demonstration of tropomyosin in the neurofibrillary pathology of Alzheimer disease. Am J Pathol 137:291-300.

Gambetti P, Autilio-Gambetti L, Manetto V, Perry G (1987) Composition of paired helical filaments of Alzheimer's disease as determined by specific probes. In: Banbury report 27, Molecular neuropathology of aging (Davies P, Finch CE, eds), pp 309-320. Cold Spring Harbor, NY: Cold Spring Harbor Laboratory.

Geisler M, Kaufman E, Fischer S, Plessmann U, Weber K (1983) Neurofilament architecture combines structural principles of intermediate filaments with carboxyl-terminal extensions increasing in size between triplet proteins. EMBO J 2:1295-1302.

Gospodarowicz D, Cheng J (1986) Heparin protects basic and acidic bFGF from inactivation. J Cell Physiol 128:465-484.

Greenberg SG, Davies P (1990) A preparation of Alzheimer paired helical filaments that displays distinct $\tau$ proteins by polyacrylamide gel electrophoresis. Proc Natl Acad Sci USA 87-5827-5831.

Hamazaki $\mathrm{H}$ (1987) $\mathrm{Ca}^{2+}$ mediated association of human serum amyloid P-component with heparan sulfate and dermatan sulfate. J Biol Chem 262:1456-1460.

Hirabayashi Y, Shimizu S, Yamada K (1989) A nitrous acid procedure as a selective histochemical means of eliminating the $\mathrm{N}$-sulfate of glycoconjugates. Histochem J 21:687-692.

Kalaria RN, Grahovac I (1990) Serum amyloid P immunoreactivity in hippocampal tangles, plaques and vessels: implications for leakage across the blood-brain barrier in Alzheimer disease. Brain Res 516: 349-353.

Kalaria RN, Galloway PG, Pcrry G (1991) Widcsprcad scrum amyloid $P$ immunoreactivity in cortical amyloid deposits and the neurofibrillary pathology of Alzheimer's disease and related disorders. Neuropathol Appl Neurobiol 17:189-201.

Khachaturian ZS (1985) Diagnosis of Alzheimer's disease. Arch Neurol 42:1097-1105.

Kisilevsky R, Snow A (1988) The potential significance of sulphated glycosaminoglycans as a common constituent of all amyloid: or, perhaps amyloid is not a misnomer. Med Hypotheses 26:231-236.

Klier FG, Cole G, Stallcup W, Schubert D (1990) Amyloid $\beta$-protein precursor is associated with extracellular matrix. Brain Res 515:336342

Ledbetter SR, Tyrell B, Hassell JR, Horigan EA (1985) Identification of the precursor protein to basement membrane heparan sulfate proteoglycans. J Biol Chem 260:8106-8113.

Ledbetter SR, Fisher LW, Hassell JR (1987) Domain structure of the basement membrane heparan sulfate proteoglycan. Biochem 26:988995.

Lee VMY, Balin BJ, Otvos L, Trojanowski JQ (1991) A68: a major subunit of paired helical filaments and derivatized forms of normal tau. Science 251:675-678.

Mann DMA, Bonshek RE, Marcyniuk B, Stoddart RW, Torgerson E (1988) Saccharides of senile plaques and neurofibrillary tangles in Alzheimer's disease. Neurosci Lett 85:277-282.

Matsumura F, Yamashiro I, Matsumura S (1985) Purification and characterization of multiple isoforms of tropomyosin from rat cultured cells. J Biol Chem 260:13851-13859.

Mayor S, Menor AK, Cross GAM, Ferguson MAJ, Dwek RA, Rademacher TW (1990) Glycolipid precursors for the membranc anchor of Trypanosoma brucei variant surface glycoproteins. J Biol Chem 265:6164-6173.

Mesulam MM, Moran MA (1987) Cholinesterases within neurofibrillary tangles related to age and Alzheimer's disease. Ann Neurol 22:223-228.

Mulvihill P, Perry G (1989) Immunoaffinity demonstration that paired helical filaments of Alzheimer disease share epitopes with neurofilaments, MAP2 and tau. Brain Res 484:150-156.

Noonan DM, Horigan EA, Ledbetter SR, Vogeli G, Sasaki M, Yamada Y, Hassel JR (1988) Identification of cDNA clones encoding different domains of the basement membrane heparan sulfate proteoglycan. J Biol Chem 263:16379-16387. 
Perry G (ed) (1987) Alterations in the neuronal cytoskeleton in Alzheimer disease, pp 229. New York: Plenum.

Perry G, Siedlak S, Kawai M, Cras P, Mulvihill P, Cordell B, Miriam Scardina J, Gambetti P (1990a) Neurofibrillary tangles, neuropil threads and senile plaques all contain abundant binding sites for basic fibroblast growth factor ( $\beta$-FGF). J Neuropathol Exp Neurol 49:318.

Perry G, Siedlak S, Mulvihill P, Kawai M, Cras P, Cordell B, Miriam Scardina J, Ledbetter S, Greenberg B, Gambetti P (1990b) Neurofibrillary tangles contain heparan sulfate proteoglycans. Neurobiol Aging 11:269.

Peterson DT, Merrick WC, Safer B (1979) Binding and release of radiolabeled eukaryotic initiation factors 2 and 3 during 805 initiation complex formation. J Biol Chem 254:2509-2516.

Potter JP, Gergely J (1975) The calcium and magnesium binding sites on troponin and their role in the regulation of myofibrillary adenosine triphosphate. J Biol Chem 250:4628-4633.

Rifkin DB, Moscatelli D (1989) Recent developments in the cell biology of basic fibroblast growth factor. J Cell Biol 109:1-6.

Rosenblatt DE, Geula C, Mesulam MM (1989) Protease nexin I immunostaining in Alzheimer's disease. Ann Neurol 26:628-634.

Saksela K, Moscatelli D, Sommer A, Rafkin DB (1988) Endothelial cell-derived sulfate binds basic fibroblast growth factor and protects it from proteolytic degradation. J Cell Biol 107:741-751.

Schreiber AB, Kenney J, Kowalski WJ, Friesel R, Mehlman T, Maciag $T$ (1985) Interaction of endothelial cell growth factor with heparin: characterization by receptor and antibody recognition. Proc Natl Acad Sci USA 82:6138-6142.

Schubert D, Schroeder R, LaCorbiere M, Saitoh T, Cole G (1988) Amyloid $\beta$ protein is possibly a heparan sulfate proteoglycan core protein. Science 241:223-224.

Schubert D, LaCorbiere M, Saitoh T, Cole G (1989) Characterization of an amyloid precursor protein that binds heparin and contains tyrosine sulfate. Proc Natl Acad Sci USA 86:2066-2069.

Seno M, Sasada R, Kurokawa T, Igarashi K (1990) Carboxyl-terminal structure of basic fibroblast growth factor significantly contributes to its affinity for heparin. Eur J Biochem 188:239-245.

Siedlak SL, Cras P, Kawai M, Richey P, Perry G (1991) Basic fibroblast growth factor binding is a marker for extracellular neurofibrillary tangles in Alzheimer's disease. J Histochem Cytochem 39:899-904.
Snow AD, Wight TN (1989) Proteoglycans in the pathogenesis of Alzheimer's disease and other amyloidoses. Neurobiol Aging 10:481497.

Snow AD, Willmer J, Kisilevsky R (1987a) Sulfated glycosaminoglycans: a common constituent of all amyloids? Lab Invest 56:120-123.

Snow AD, Willmer J, Kisilevsky R (1987b) A close ultrastructural relationship between sulfated proteoglycans and AA amyloid fibrils. Lab Invest 57:687-698.

Snow AD, Mar H, Nochlin D, Kimata K, Kato M, Suzuki S, Hassell J, Wight TN (1988) The presence of heparan sulfate proteoglycans in the neuritic plaques and congophilic angiopathy in Alzheimer's disease. Am J Pathol 133:456-463.

Snow AD, Lara S, Nochlin D, Wight TN (1989) Cationic dyes reveal proteoglycans structurally integrated within the characteristic lesions of Alzheimer's disease. Acta Neuropathol (Berl) 78:113-123.

Snow AD, Mar H, Nochlin D, Sekiguchi RT, Klimata K, Koike Y, Wight TN (1990) Early accumulation of heparan sulfate in neurons and in the beta amyloid protein containing lesions in Alzheimer's disease and Down's syndrome. Am J Pathol 137:1253-1270.

Sparkman DR, Hill SJ, White CL (1990) Paired helical filaments are not the major binding sites for wheat germ and Dolichos fiflorus agglutinins in the neurofibrillary tangles of Alzheimer's disease. Acta Neuropathol 79:640-646.

Szumanska G, Vorbrodt AW, Mandybur TI, Wisniewski HM (1987) Lectin histochemistry of plaques and tangles in Alzheimer's disease. Acta Neuropathol (Berl) 73:1-11.

Taniuchi M, Schweitzer JB, Johnson EM (1986) Nerve growth factor receptor molecules in rat brain. Proc Natl Acad Sci USA 83:19501954.

Ueda K, Masliah E, Saitoh T, Bakalis SL, Scoble H, Kosik KS (1990) Alz-50 recognizes a phosphorylated epitope of tau protein. J Neurosci 10:3295-3304

Yayon A, Kingsbrun M, Esko JD, Leder P, Ornitz DM (1991) Cell surface, heparin-like molecules are required for binding of basic fibroblast growth factor to its high affinity receptor. Cell 64:841-848.

Yurchenco PD, Johannes SC (1990) Molecular architecture of basement membranes. FASEB J 4:1577-1590. 